\title{
Obliczanie objętości materii organicznej (TOC) na podstawie inwersji genetycznej danych sejsmicznych
}

\begin{abstract}
W artykule została zaprezentowana metodyka wyznaczania rozkładu parametru TOC na danych sejsmicznych 3D na podstawie inwersji genetycznej. Zaprezentowany schemat obliczeń zastosowano na danych sejsmicznych pochodzących z obszaru północnej Polski. Głównym celem przeprowadzonych badań było rozpoznanie dwóch, wyinterpretowanych horyzontów sejsmicznych (z których pierwszy odpowiadał powierzchni stropowej ogniwa Jantaru, a drugi stropowi formacji z Sasina), pod kątem wyznaczenia stref potencjalnych sweet spotów. Wyinterpretowany rozkład parametrów fizycznych takich jak: prędkość i gęstość, oraz parametrów petrofizycznych takich jak: porowatość, nasycenie, a także TOC w obrębie kolejnych sekwencji skalnych, ma ścisły związek z parametrami sejsmicznymi, takimi jak czasy przejścia fal odbitych od poszczególnych granic sejsmicznych oraz ich charakterystyk amplitudowych i częstotliwościowych $[1,8]$. Zaprezentowana metodyka wyznaczania rozkładu parametru TOC była realizowana na podstawie zmienności amplitud pola falowego, pola prędkości fal podłużnych oraz pomiarów labolatoryjnych TOC w otworach wiertniczych. Uzyskane wyniki w postaci map i rozkładów przestrzennych pozwalają zidentyfikować obszary perspektywiczne o podwyższonych wartościach TOC, a ich dokładność uwarunkowana jest rozdzielczością danych sejsmicznych.
\end{abstract}

Słowa kluczowe: TOC, inwersja genetyczna, impedancja akustyczna, shale gas.

\section{Calculation of organic matter volume (TOC) based on genetic inversion of seismic data}

The article presents the methodology for determining the distribution of TOC parameter on 3D seismic data, based on genetic inversion. The presented calculation scheme was applied on seismic data from the northern area of Poland. The main goal of the study was to recognize two seismic horizons (the first of which corresponded to the top surface of the Jantar Member and the second to the top of the Sasino Formation), in terms of designating the zones of potential sweet spots. The interpreted distribution of physical parameters such as: velocity and density and petrophysical parameters, such as: porosity, saturation and TOC within successive rock sequences, is closely related to seismic parameters, such as transition times of waves reflected from individual seismic boundaries and their amplitude characteristics and frequency [1,8]. The presented methodology for determining the distribution of the TOC parameter, was based on the variability of the wave field amplitudes, the field of longitudinal wave velocities and laboratory TOC measurements in wellbores. Obtained results in the form of maps and spatial distributions allow to identify perspective areas with increased TOC values, and their accuracy is conditioned by the resolution of seismic data.

Keywords: TOC, genetic inversion, acoustic impedance, shale gas.

\section{Wprowadzenie}

Zasobność skały w substancję organiczną (TOC) jest kluczowym parametrem, analizowanym dla złóż niekonwencjonalnych typu shale oil / gas. Stopień zawartości materii organicznej jest definiowany jako procentowy wagowy udział całkowitego węgla organicznego w skale, w skrócie TOC (Total Organic Carbon).
Przyjęto, że skała łupkowa, aby mogła stać się celem poszukiwań niekonwencjonalnych, powinna zawierać powyżej 1\% wag. TOC. Na przykład w formacjach łupkowych zawierających gaz ziemny w USA średnia zawartość TOC w kompleksie złożowym zawiera się najczęściej w przedziale $1,3 \div 4 \%$ wag. [11]. Wartości TOC w lupkach ordowiku i syluru 
Polski rzadko przekraczają 2\% [4]. Parametr TOC na ogół dobrze koreluje z wysokimi wartościami profilowania gamma, niskimi wartościami gęstości objętościowej [7] i wysokimi wartościami czasów interwałowych $(\Delta T)$, rejestrowanych za pomocą profilowania akustycznego $[5,7]$.

Badania prowadzone przez Passeya i innych [9] wykazały, że oszacowanie wielkości TOC na podstawie porowatości całkowitej stanowi znaczny problem, w związku z tym wspomniani autorzy zaprezentowali inne metody estymacji TOC przy wykorzystaniu profilowania akustycznego i profilowania oporności. Inną metodę estymacji TOC, zdefiniowaną jako sejsmiczna inwersja TOC, w której połączono sejsmiczne parametry prędkości fali podłużnej Vp i poprzecznej Vs oraz gę- stość objętościową z pomiarami laboratoryjnymi TOC w otworach, zaprezentowano w artykule Liu [7]. Autor ten przedstawia metodę estymacji anizotropowych parametrów Thomsena za pomocą sejsmicznej inwersji anizotropowej, która wykorzystuje dane sejsmiczne pełnego azymutu i kolekcje kątowe (Full-Azimuth Seismic Angle Gathers).

W niniejszym artykule została zaprezentowana metodyka estymacji parametru TOC, wykorzystująca inwersję genetyczną, obliczaną na danych sejsmicznych na podstawie zmienności rozkładu amplitud pola falowego, pola prędkości fal podłużnych oraz labolatoryjnych pomiarów wartości TOC w otworach wiertniczych. Dane sejsmiczne oraz geofizyczne użyte do obliczenia rozkładu TOC pochodziły z obszaru basenu bałtyckiego.

\section{Obszar badań}

Obszar objęty prezentowanymi badaniami zlokalizowany jest na terenie basenu bałtyckiego, w północnej Polsce (rysunek 1a). Profil litostratygraficzny, reprezentowany przez utwory kambru, ordowiku, syluru, cechsztynu, triasu, jury, kredy oraz kenozoiku, rozpoznano w analizowanych odwiertach: L-1 oraz O-2, O-3 i O-4 (rysunek 1b). Przedmiotem największego zainteresowania były utwory syluru, należące do ogniwa z Jantaru, oraz utwory ordowiku należące do formacji z Sasina, które uznane zostały za najbardziej perspektywiczne pod kątem poszukiwań złóż o charakterze niekonwencjonalnym. Utwory ogniwa z Jantaru reprezentowane są przez serię iłowców i mułowców z bardzo licznymi graptolitami, podczas gdy formacja z Sasina zbudowana jest głównie z czarnych iłowców z liczną fauną graptolitów. Obydwa ogniwa litostratygraficzne rozdziela formacja margli i iłowców z Prabut [10].
Interpretacja horyzontów sejsmicznych wykonana została przy użyciu oprogramowania Petrel firmy Schlumberger. Dowiązanie danych otworowych i stratygraficznych do horyzontów sejsmicznych zostało wykonane na podstawie obliczonego sejsmogramu syntetycznego. W wyniku dopasowania wyznaczono granicę sejsmiczną dla stropu ogniwa z Jantaru, której wartość amplitudy wynosiła zero, natomiast dla stropu formacji z Sasina przyjęto maksimum ujemnej amplitudy (rysunek 2).

Należy zaznaczyć, że w sąsiedztwie stref dyslokacyjnych oraz w częściach brzegowych zdjęcia sejsmicznego 3D wyznaczenie horyzontów związanych z analizowanymi jednostkami, tj. stropem ogniwa z Jantaru oraz stropem formacji z Sasina, było utrudnione ze względu na zmienność i osłabienie sygnału sejsmicznego.

b)

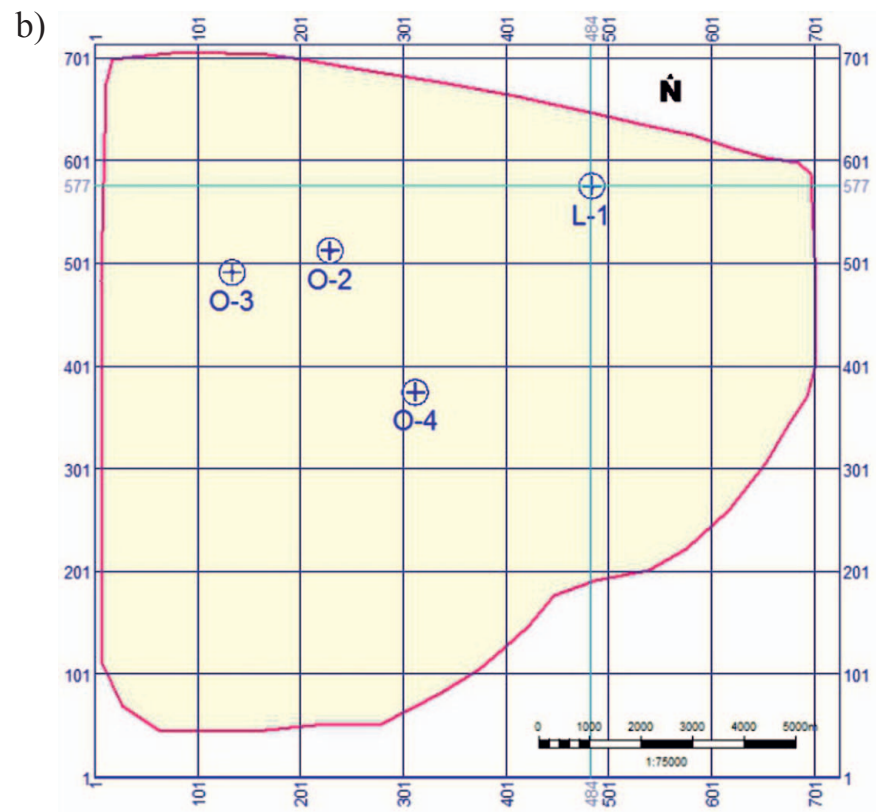

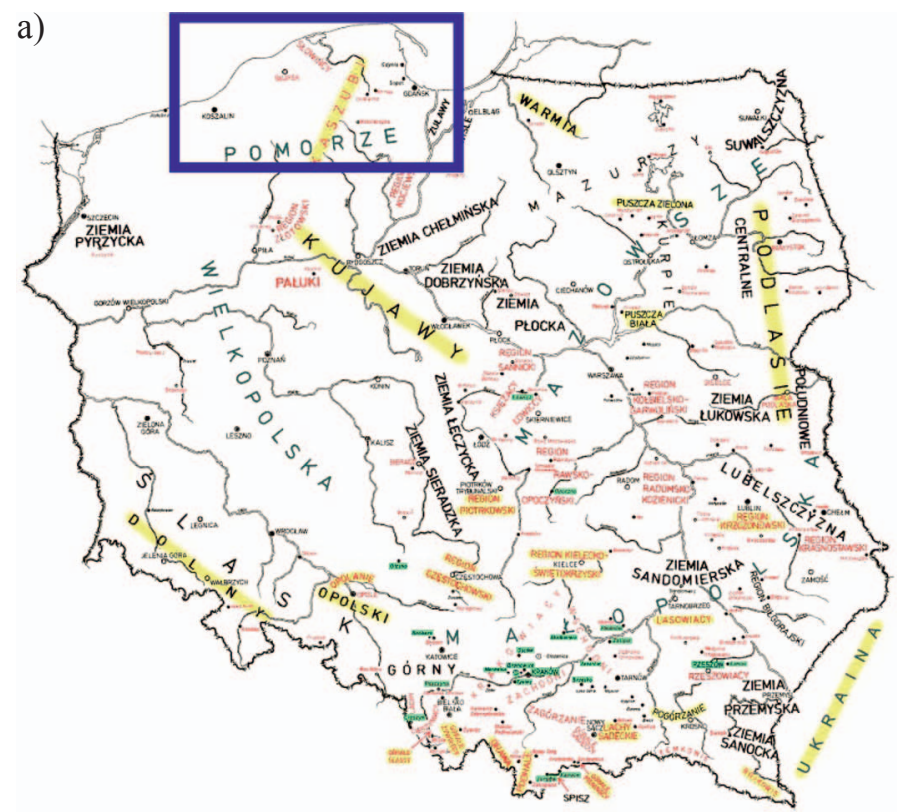

Rys. 1. a) - lokalizacja obszaru badań, b) - obszar zdjęcia sejsmicznego 3D wraz z lokalizacją odwiertów wykorzystanych w opracowaniu 


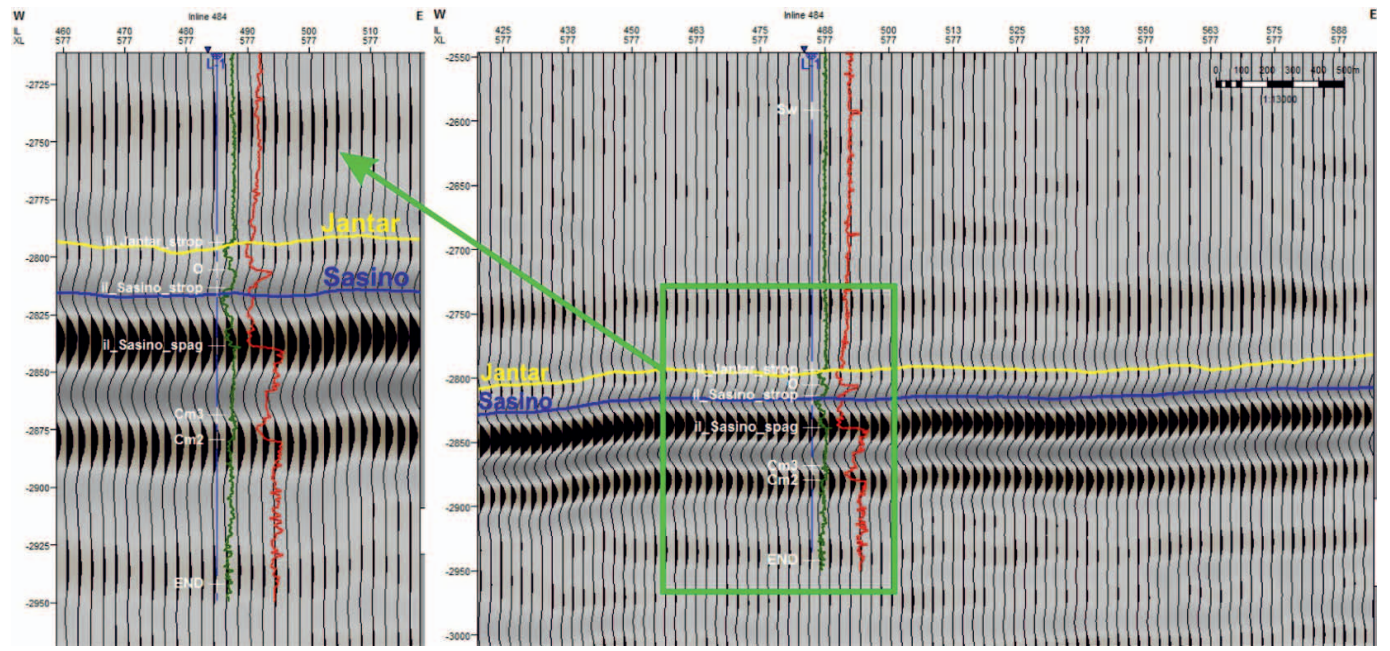

Rys. 2. Interpretacja stropów Jantaru i Sasina w pozycji otworu L-1 na danych sejsmicznych 3D

\section{Inwersja sejsmiczna dla fal podłużnych}

Inwersja sejsmiczna jest procesem umożliwiającym lepsze odwzorowanie własności petrofizycznych i parametrów fizycznych ośrodka geologicznego na bazie danych geofizycznych w postaci zmian impedancji, będącej iloczynem gęstości i prędkości propagacji fali akustycznej, wynikającej ze zmienności litologicznej ośrodka skalnego, zróżnicowanej porowatości, zmian nasycenia przestrzeni porowej, jak również zmiennej zawartości materii organicznej TOC $[2,3]$.

Wzrost zawartości TOC powoduje zmniejszenie prędkości [5] i gęstości [7]. W związku z tym możliwa jest estymacja zawartości TOC na podstawie inwersji sejsmicznej z danych 3D.
Z uwagi na sposób obliczania inwersji sejsmicznej można wyróżnić dwie główne metody: deterministyczną oraz probabilistyczną $[3,12]$. W obliczeniach wykonanych w ramach niniejszego opracowania wykorzystano inwersję deterministyczną, która była obliczana przy użyciu modułu Quantitative Interpretation oprogramowania Petrel firmy Schlumberger do wyznaczenia pola prędkości, które zostało użyte jako zmienna niezależna $w$ inwersji genetycznej.

Parametrami wejściowymi, użytymi w obliczeniach inwersji sejsmicznej, były dane $\mathrm{z}$ otworów L-1, O-2, O-3, O-4 w postaci profilowania akustycznego (DT) i profilowania gę-

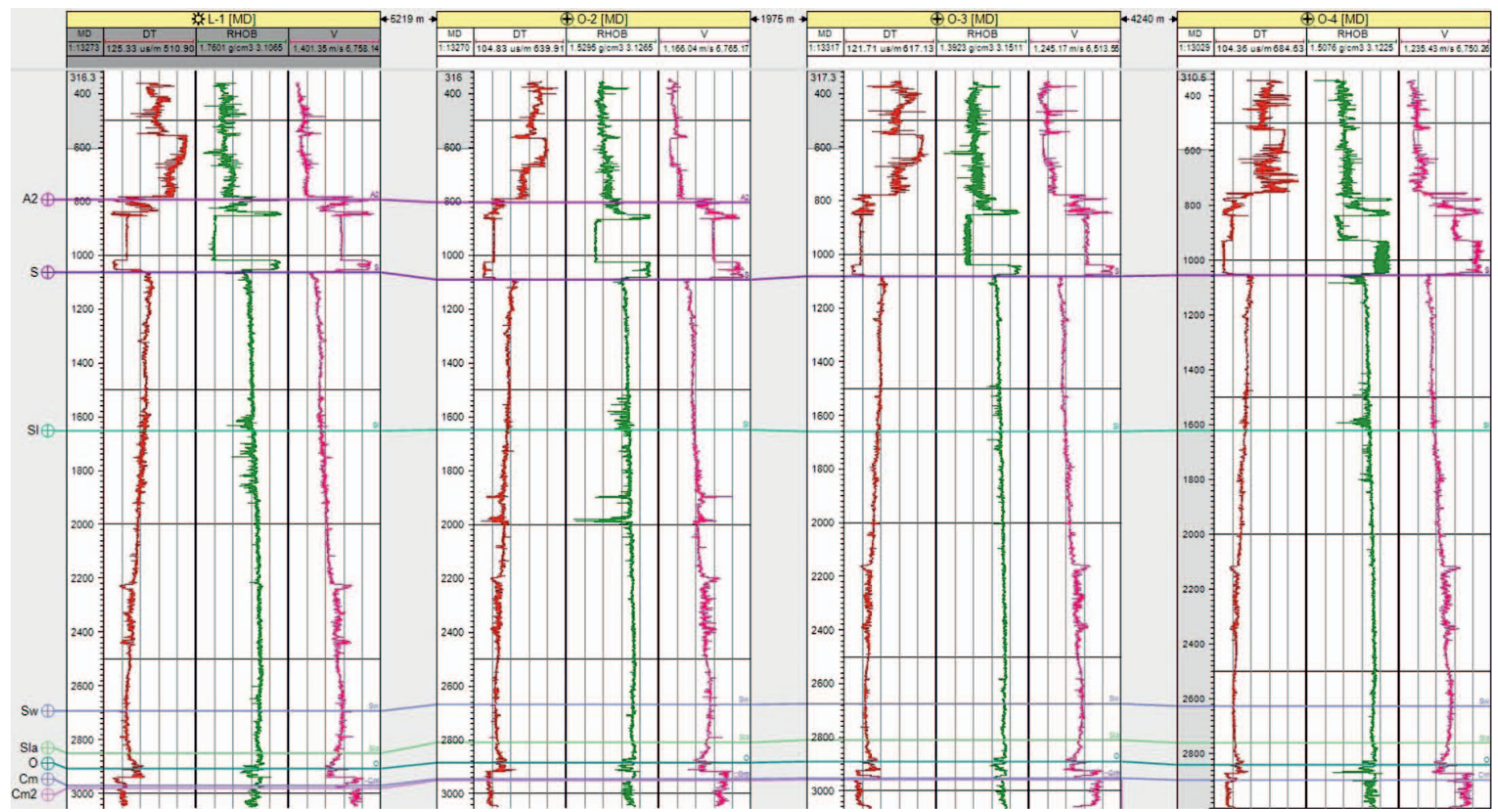

Rys. 3. Zestawienie profilowania czasu interwałowego DT, gęstości objętościowej RHOB i prędkości fali podłużnej $V$ dla otworów L-1, O-2, O-3, O-4, wykorzystane w obliczeniach inwersji sejsmicznej 


\section{NAFTA-GAZ}

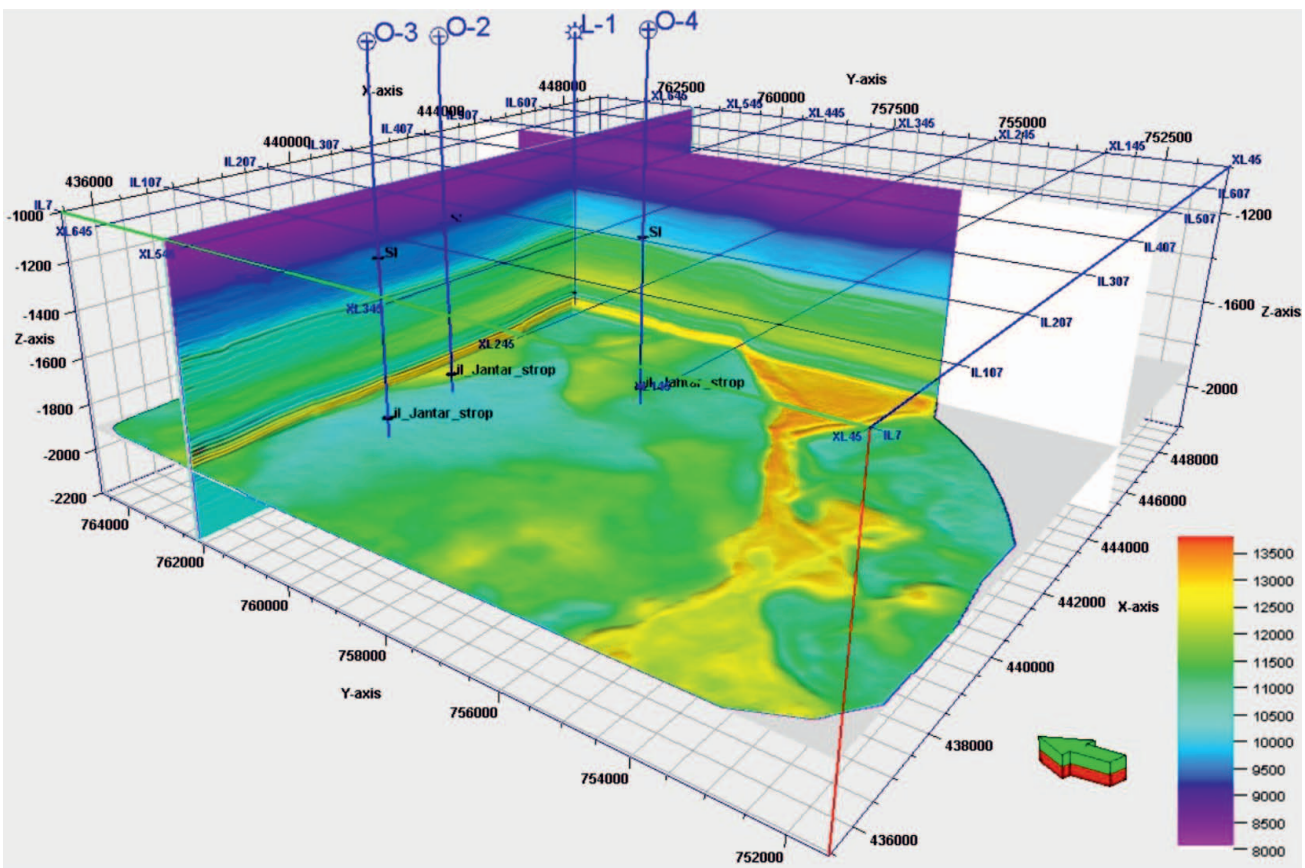

Rys. 4. Wyniki obliczeń impedancji akustycznej 3D

stości objętościowej (RHOB) (rysunek 3), dane sejsmiczne 3D, $\rho$ - gęstość objętościowa $\left(\mathrm{g} / \mathrm{cm}^{3}\right)$,

sygnał elementarny oraz model niskoczęstotliwościowy obli- $\quad V$ - prędkość propagacji fali podłużnej PP (m/s),

czony na podstawie danych otworowych. W wyniku obliczeń obliczono rozkład prędkości na danych sejsmicznych 3D inwersji sejsmicznej na danych sejsmicznych 3D otrzymano (rysunek 5). Do obliczeń wykorzystano wolumen gęstości rozkłady impedancji akustycznej (rysunek 4).

Korzystając z relacji:

$$
A I=\rho \cdot V
$$

gdzie:

$A I$ - impedancja akustyczna, dla danych sejsmicznych 3D opracowany przez Geofizykę Toruń SA.

Uzyskane wyniki w postaci wartości prędkości akustycznych (rysunek 5) dla zdjęcia sejsmicznego 3D wykazują dobre dopasowanie do danych otworowych oraz dużą dynamikę zmienności (rysunek 6).

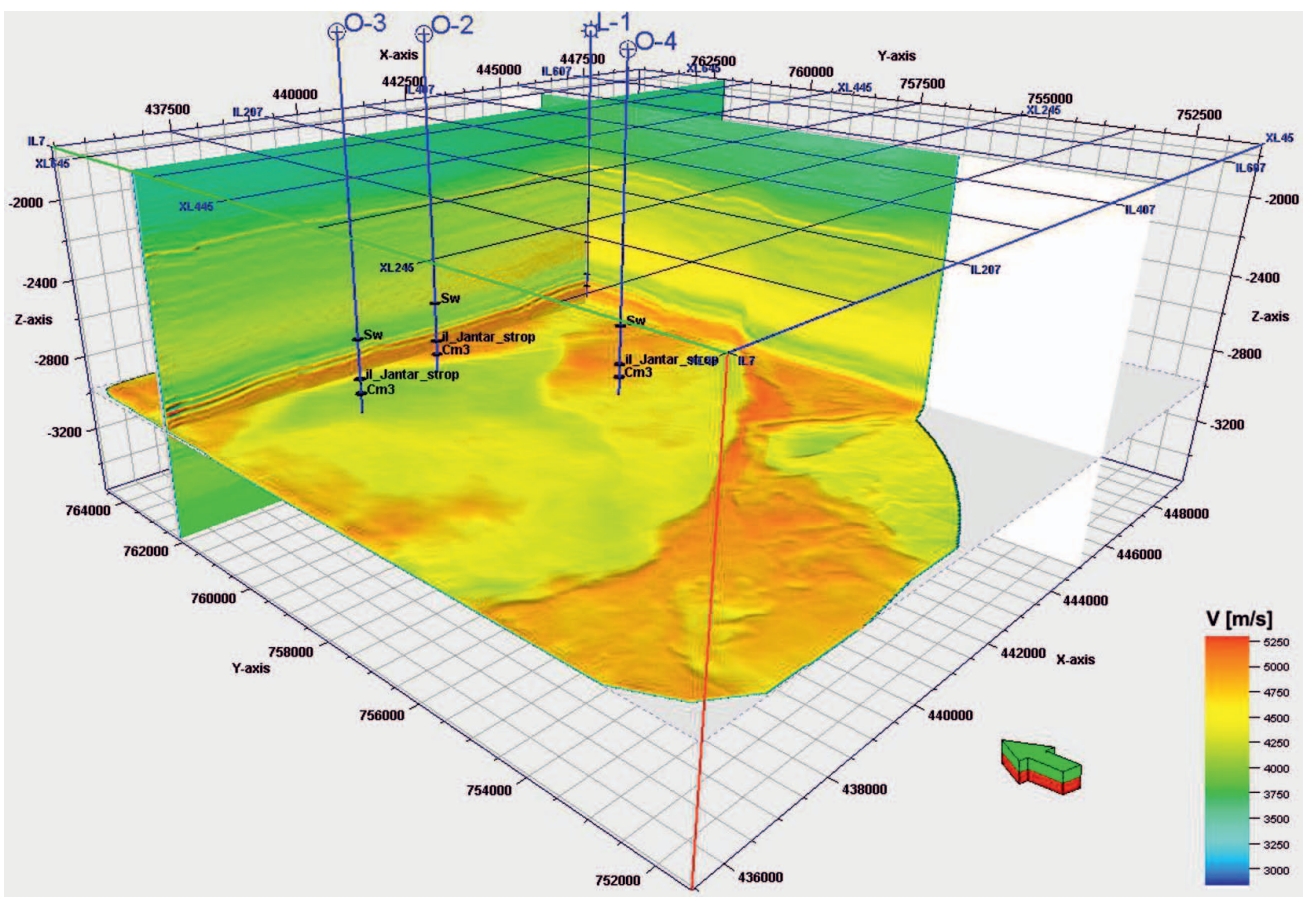

Rys. 5. Rozkład obliczonych prędkości akustycznych zdjęcia sejsmicznego 3D 


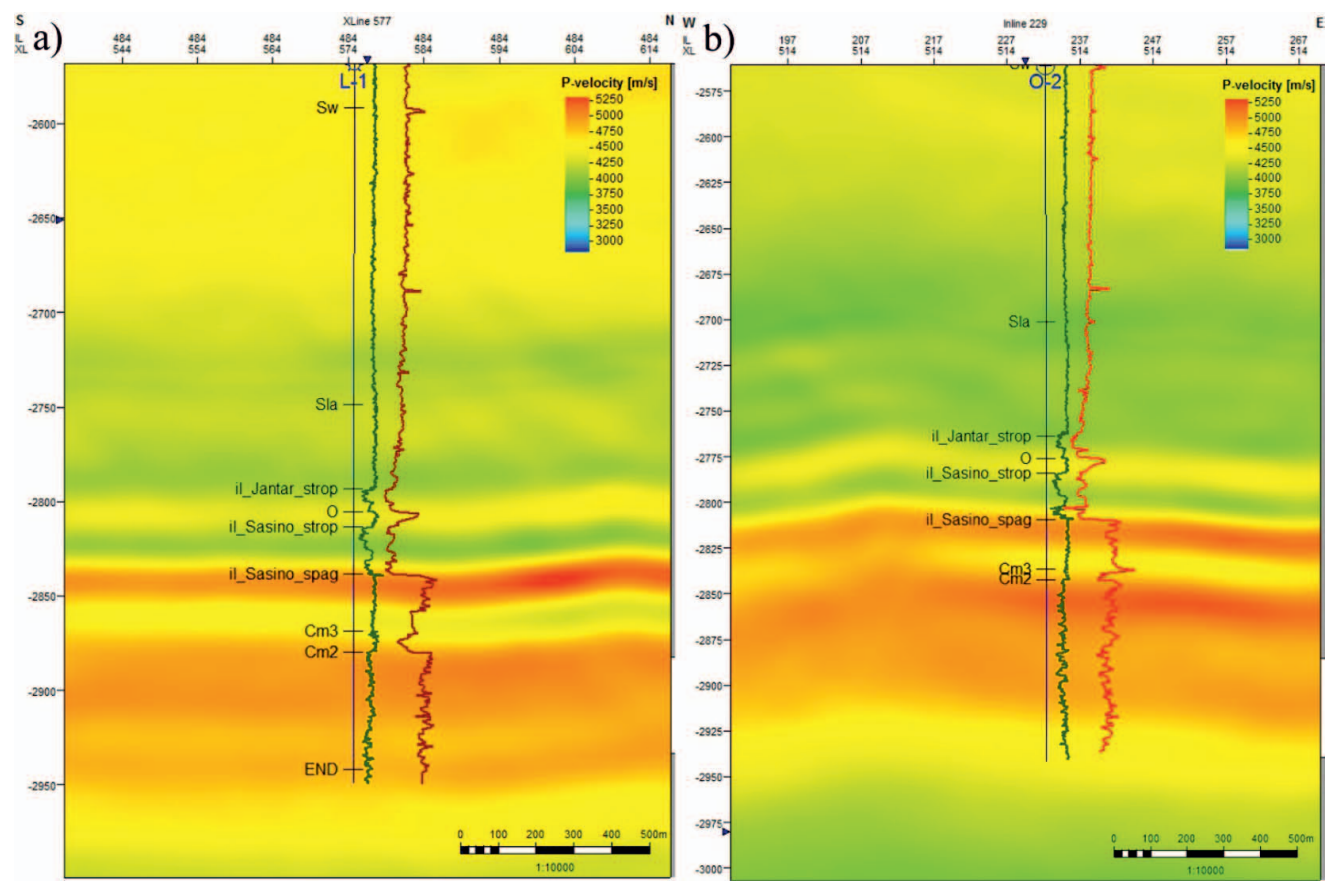

Rys. 6. Przekroje sejsmiczne XL544 i XL514 obliczonych prędkości akustycznych z dopasowaniem profilowań geofizycznych gęstości objętościowej RHOB (krzywa zielona) i prędkości fali podłużnej $V$ (krzywa czerwona) otworów L-1 i O-2

\section{Obliczenie parametru TOC na podstawie danych sejsmicznych}

Estymację parametru TOC wyznaczono na podstawie inwersji genetycznej. Inwersja genetyczna umożliwia obliczenie dowolnego parametru (zmiennej zależnej), określanej poprzez udział zmiennych niezależnych (dane sejsmiczne i otworowe). Autorzy wykorzystali moduł do obliczania inwersji genetycznej, wchodzący w skład oprogramowania Petrel firmy Schlumberger, który wykorzystuje do obliczeń algorytm sieci neuronowych [6]. Zaletą tej metody w stosunku do klasycznej inwersji sejsmicznej jest to, że na podstawie danych sejsmicznych i otworowych można oszacować nie tylko impedancję akustyczną, ale także inne parametry (prędkość, gęstość, porowatość), które wykazują dobrą korelację z danymi sejsmicznymi. Natomiast jej wadą jest konieczność wykonywania dużej ilości testów tak, aby dopasowanie wzorca do wyniku osiągnęło odpowiednio zadowalający poziom. Czas obliczeń zwiększa się wraz ze wzrostem ilości danych wejściowych, wykorzystanych w procesie uczenia, jak również $\mathrm{z}$ większą objętością wolumenów sejsmicznych.

Zmiennymi biorącymi udział w modelu uczenia sieci neuronowych, estymujących zawartość TOC były: rozkład amplitud pola falowego (dane sejsmiczne 3D), rozkład obliczonego pola prędkości 3D oraz wyniki analiz laboratoryjnych zawartości TOC w otworach L-1, O-2, O-3, O-4, wykonanych w Zakładzie Geologii i Geochemii INiG - PIB. Ostateczny, najbardziej optymalny wynik estymacji zawartości TOC uzyskano na podstawie wielokrotnych iteracji doboru wartości poszczególnych parametrów. Jako zmienne niezależne do obliczeń TOC przyjęto dane w otworach O-2, O-3, O-4, natomiast otwór L-1 był otworem weryfikującym wyniki obliczeń.

Współczynnik korelacji dla obliczanego modelu wynosi 0,80 . Wartość współczynnika korelacji dla wybranego otworu L-1 wyniosła 0,78 przy liczbie pomiarów laboratoryjnych 175 . W przypadku poszczególnych otworów współczynniki korelacji wyniosły odpowiednio: w otworze O-2 - 0,76 (przy liczbie pomiarów laboratoryjnych 168), w otworze O-3 - 0,84 (196), w otworze O-4 - 0,78 (98). Uzyskana wartość współczynnika korelacji wskazuje na dobre dopasowanie modelu do danych rzeczywistych TOC. Otrzymany model może być z powodzeniem wykorzystany do estymacji TOC na całym wolumenie sejsmicznym.

Graficzna ilustracja wyników estymacji dla poszczególnych otworów została zaprezentowana na rysunku 7.

Efektem zastosowania utworzonego modelu estymacji TOC do danych sejsmicznych jest jego przestrzenny rozkład, zaprezentowany na rysunkach $8-11$. Porównując wyniki, stwierdzić można, że rozkład TOC uzyskany na podstawie danych sejsmicznych nie jest tak szczegółowy jak rozrzut wartości otrzymanych na podstawie badań laboratoryjnych. Główną przyczyną tej rozbieżności jest różna rozdzielczość danych. Maksymalna rozdzielczość danych sejsmicznych $w$ analizowanym interwale wynosi około $25 \mathrm{~m}$, a wyników badań laboratoryjnych około $10 \mathrm{~cm}$. Zdecydowanie mniejsza rozdzielczość danych sejsmicznych uniemożliwia szczegółowe odwzorowanie zawartości TOC w ośrodku geologicznym. Wartości TOC są 


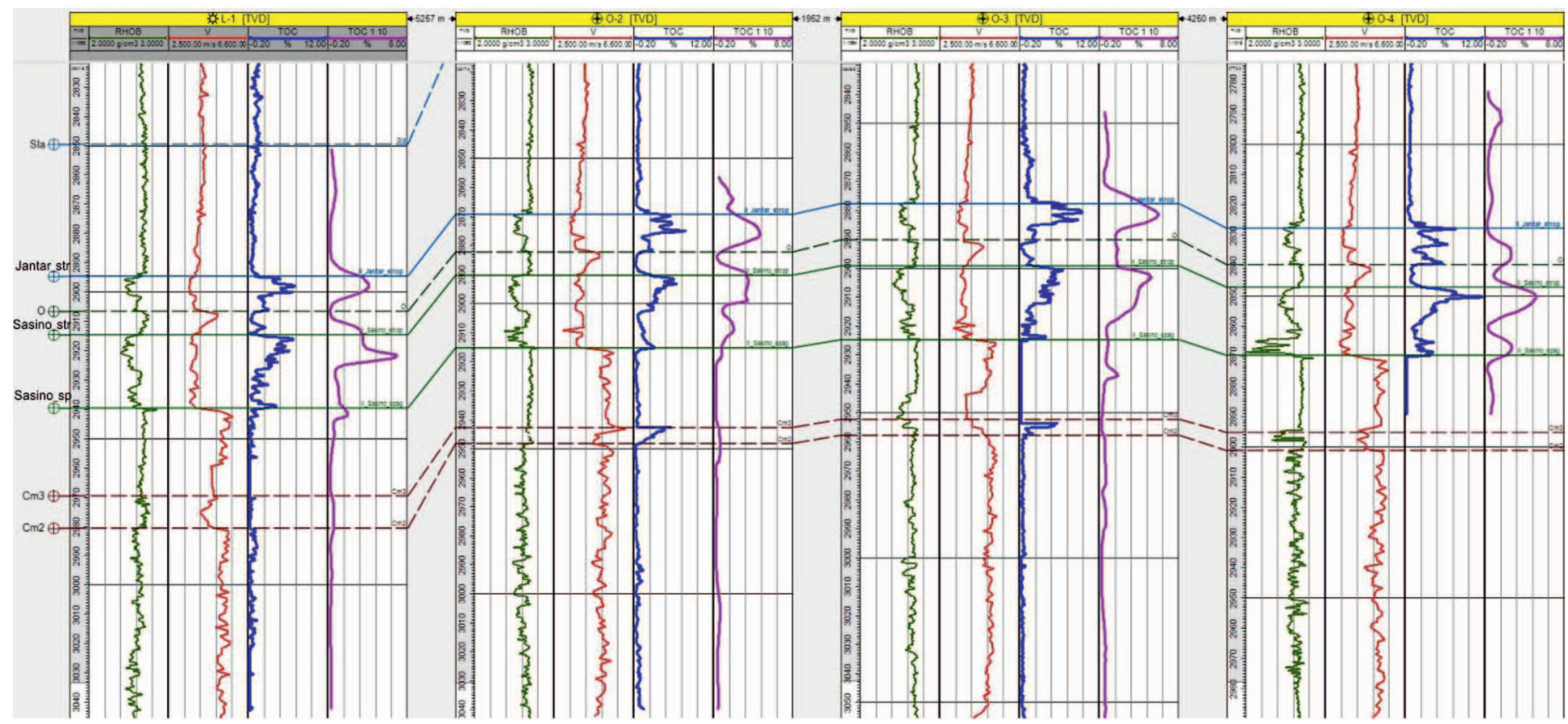

Rys. 7. Wynik estymacji parametru TOC dla otworów L-1, O-2, O-3, O-4; krzywa zielona - RHOB, krzywa czerwona $-V$, krzywa granatowa - TOC wyznaczone w Zakładzie Geologii i Geochemii INiG - PIB, krzywa purpurowa - wynik estymacji parametru TOC_1_10

uśrednione w przedziałach głębokościowych odpowiadających rozdzielczości danych sejsmicznych (rysunek 8).

W celu przestrzennego zobrazowania rozkładu parametru TOC na analizowanym obszarze badań, wyekstrahowano maksymalne wartości TOC w interwałach głębokościowych, obejmujących ośrodek geologiczny nad i pod wyinterpretowanymi horyzontami sejsmicznymi ogniwa $\mathrm{z}$ Jantaru i formacji z Sasina (rysunki 9-11). Dla horyzontu odpowiadającego powierzchni stropowej ogniwa z Jantaru przyjęto inter- wał $+3 \mathrm{~m}$ do $-4 \mathrm{~m}$, natomiast dla stropu formacji z Sasina $+4 \mathrm{~m}$ do $-8 \mathrm{~m}$. Na prezentowanych mapach rozkładu maksymalnej zawartości TOC (rysunek 9) można zaobserwować obszary o wysokiej koncentracji TOC, które lokalizują się w otoczeniu otworu L-1 oraz na południowy wschód od niego dla obydwu jednostek (ogniwa z Jantaru oraz formacji z Sasina). Dla przyjętego interwału ogniwa z Jantaru dodatkowo zaznacza się podwyższona zawartość TOC w obrębie stref przyuskokowych.

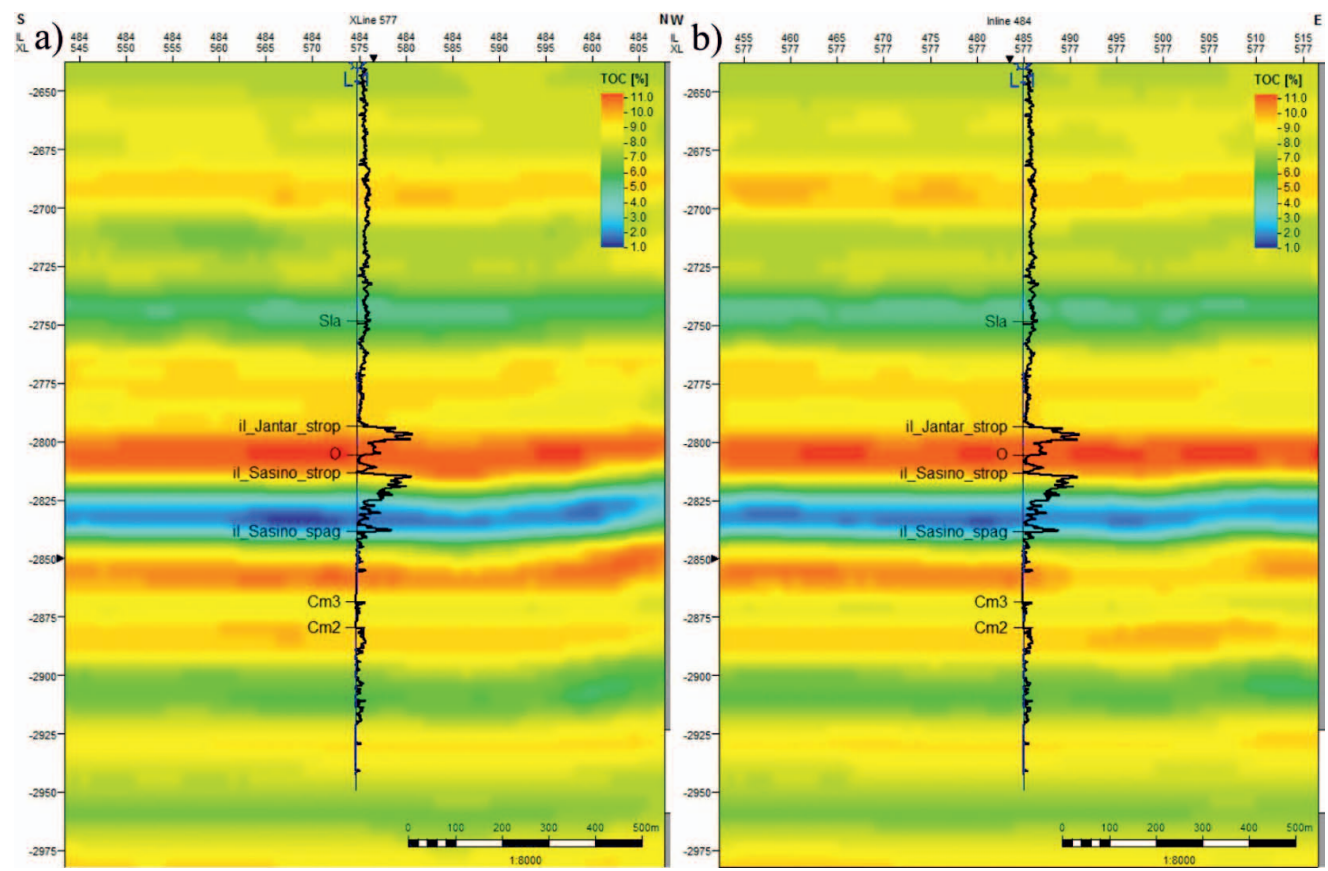

Rys. 8. Rozkład parametru TOC dla linii IL484 i XL577 w pozycji otworu L-1; krzywa czarna - TOC wyznaczona w Zakładzie Geologii i Geochemii INiG - PIB 


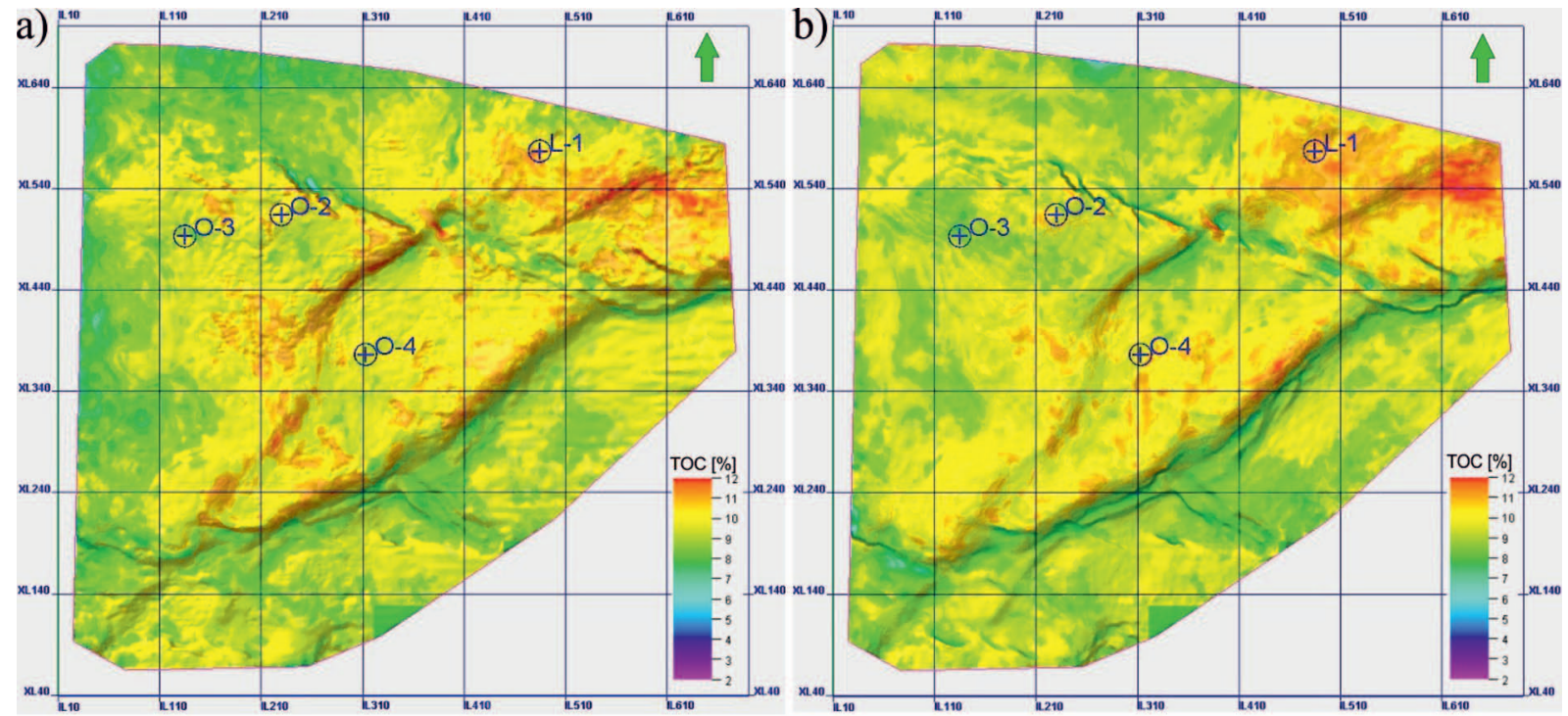

Rys. 9. Mapy rozkładu maksymalnej zawartości TOC dla stropów ogniwa z Jantaru (a) oraz formacji z Sasina (b) na podstawie danych sejsmicznych Opalina 3D

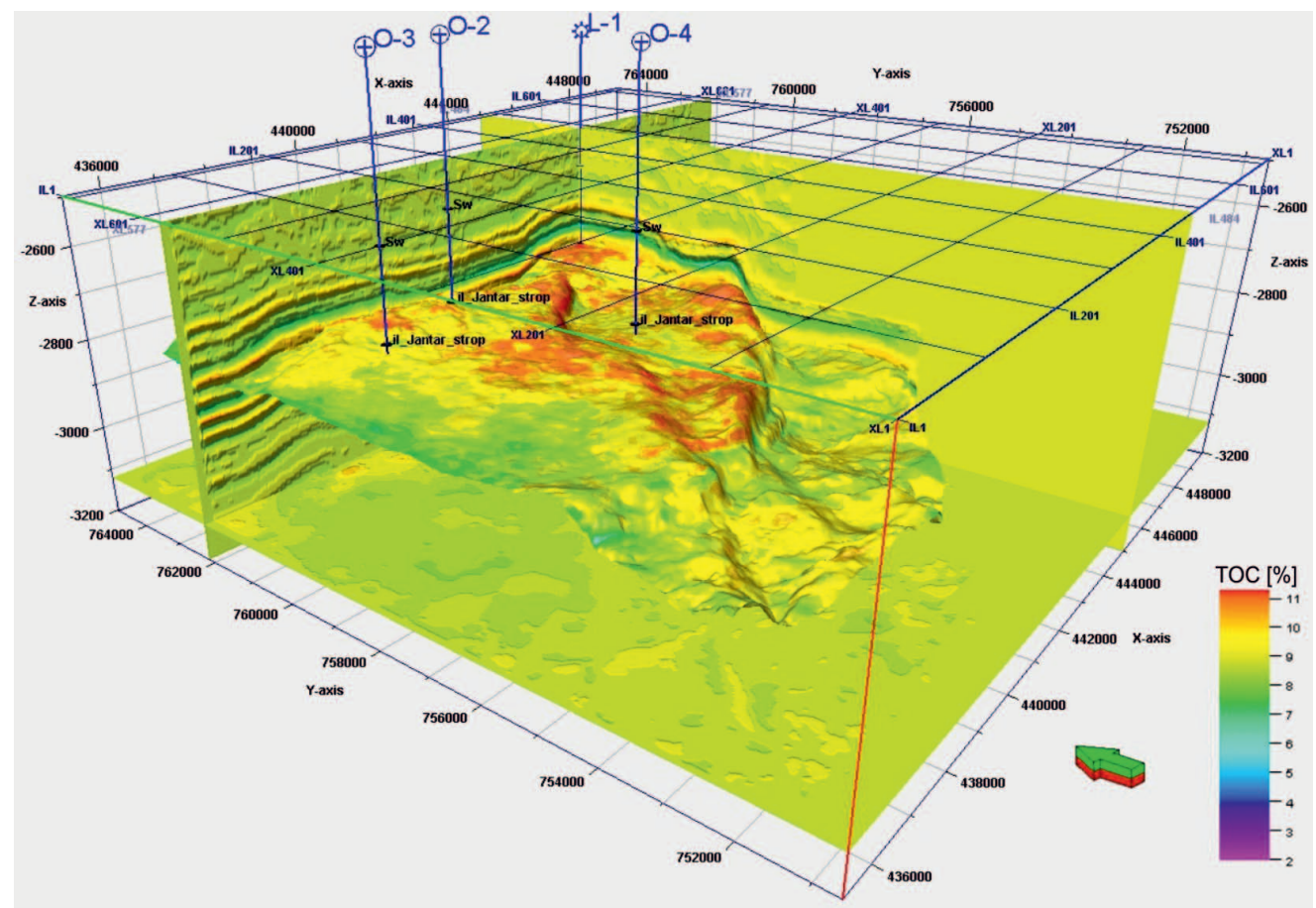

Rys. 10. Przestrzenny rozkład parametru TOC dla stropu ogniwa z Jantaru

\section{Podsumowanie i wnioski}

1. Uzyskane rezultaty potwierdzają użyteczność wykorzystania inwersji genetycznej w celu wyznaczenia parametru TOC w utworach geologicznych w formacjach łupkowych.

2. Zaprezentowana metodyka wyznaczania rozkładu parametru TOC na danych sejsmicznych na podstawie inwersji genetycznej pozwoliła na identyfikację obszarów potencjalnie perspektywicznych, charakteryzujących się większymi wartościami TOC.
3. Dokładność tej metody uwarunkowana jest rozdzielczością danych sejsmicznych.

4. Otrzymane rezultaty rozkładu parametru TOC na podstawie zastosowanej metodyki obliczania bazującej na wynikach inwersji sejsmicznej, dają podstawę do jej praktycznego wykorzystania w procesie poszukiwania złóż o charakterze niekonwencjonalnym w formacjach łupkowych. 


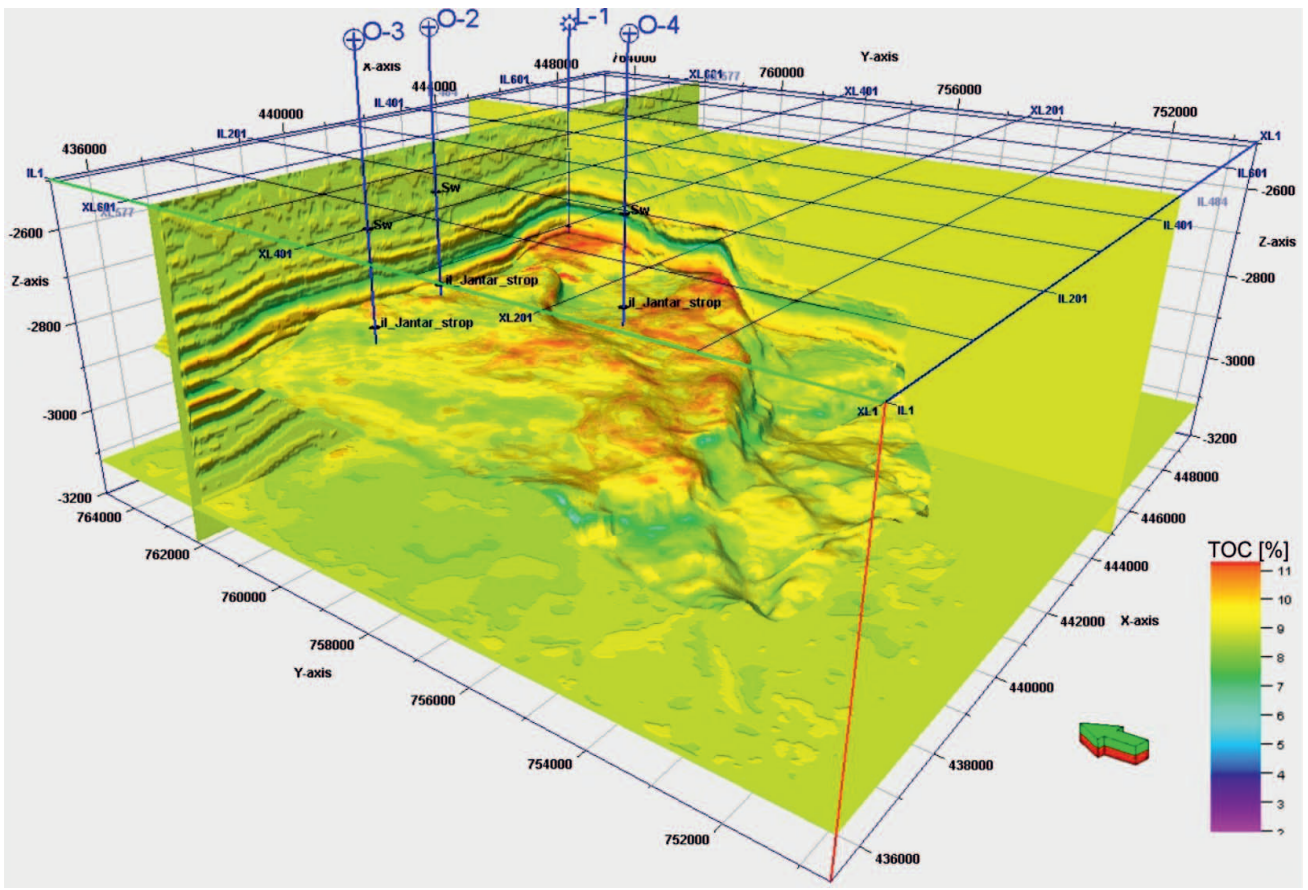

Rys. 11. Przestrzenny rozkład parametru TOC dla stropu ogniwa z Sasina

Artykuł nadesłano do Redakcji 29.01.2018 r. Zatwierdzono do druku 30.03.2018 r.

Artykuł powstał na podstawie badań zrealizowanych w ramach projektu pt.: Metodologia wyznaczania sweet spotów na podstawie własności geochemicznych, petrofizycznych, geomechanicznych w oparciu o korelację wyników badań laboratoryjnych z pomiarami geofizycznymi i model generacyjny 3D - dofinansowanego przez Narodowe Centrum Badań i Rozwoju w ramach programu Blue Gas - Polski Gaz Łupkowy; nr umowy: BG1/MWSSSG/13.

\section{Literatura}

[1] Glaser K.S., Miller C.K., Johnson G.M., Toelle B., Kleinberg R.L., Miller P., Pennington W.D.: Seeking the sweet spot: Reservoir and completion quality in organic shales. Oilfield Review, Winter 2013/2014, nr 4, s. 16-29.

[2] Jędrzejowska-Tyczkowska H.: Inwersja sejsmiczna akustyczna $i$ elastyczna fal podtużych, konwertowanych $i$ poprzecznych $w$ zagadnieniach interpretacji złożowej. Prace INiG 2009, nr 160, s. 1-85.

[3] Jędrzejowska-Tyczkowska H., Bartoń R.: Współczesne możliwości metody sejsmicznej w zadaniach ilościowej charakterystyki obiektów złożowych. Nafta-Gaz 2005, nr 7-8, s. 349.

[4] Karcz P., Janas M., Dyrka I.: Polskie złoża gazu ziemnego z łupków na tle wybranych niekonwencjonalnych złóż Europy Środkowo-Wschodniej. Przegląd Geologiczny 2013, vol. 61, nr 7, s. $411-423$.

[5] Leginowicz A.: Identyfikacja sweet spotów w poszukiwaniach złóż niekonwencjonalnych. Nafta-Gaz 2016, nr 4, s. 223-229, DOI: 10.18668/NG.2016.04.01.

[6] Leginowicz A., Pirowska K.: Estymacja parametrów charakteryzujacych ośrodek geologiczny za pomoca procedury inwersji genetycznej. Nafta-Gaz 2013, nr 5, s. 392-400.

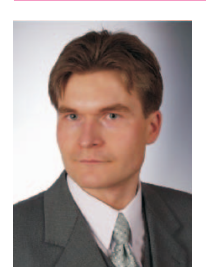

Dr inż. Robert BARTOŃ

Adiunkt w Zakładzie Sejsmiki.

Instytut Nafty i Gazu - Państwowy Instytut Badawczy ul. Lubicz 25 A

31-503 Kraków

E-mail: robert.barton@inig.pl
[7] Liu X.: Workflows for sweet spots identification in shale plays using seismic inversion and well logs. GeoConvention 2013, Integration: Geoscience Engineering Partnership, Calgary 6-12.05.2013.

[8] Matyasik I., Jędrzejowska-Tyczkowska H.: Niekonwencjonalne złoża gazu - ryzyko, niepewność, intuicja czy udokumentowana teoria, poprawnie uwarunkowane równania i potwierdzenie zdarzeniami z praktyki. Wiadomości Naftowe i Gazownicze 2010, vol. 147, nr 7, s. 4-13.

[9] Passey Q.R., Creaney S., Kulla J.B., Moretti F., Stroud J.D.: A practical model for organic richness from porosity and resistivity $\log$. The AAPG Bulletin 1990, vol. 74, nr 12, s. 1777-1794.

[10] Podhalańska T., Waksmundzka M.I., Becker A., Roszkowska-Remin J.: Rozpoznanie stref perspektywicznych wystepowania niekonwencjonalnych złóż weglowodorów w Polsce-nowe wyniki oraz dalsze kierunki badań. Przegląd Geologiczny 2016, vol. 64, nr 12, s. 953-962.

[11] Poprawa P.: Potencjał występowania złóż gazu ziemnego w tupkach dolnego paleozoiku w basenie baltyckim i lubelsko-podlaskim. Przegląd Geologiczny 2010, vol. 58, nr 3, s. 226-249.

[12] Veeken P., Silva M.: Seismic inversion methods and some of their constraints. First Break 2004, vol. 22.
Mgr inż. Aleksander WILK

Główny specjalista inżynieryjno-techniczny w Zakładzie Sejsmiki. Instytut Nafty i Gazu - Państwowy Instytut Badawczy ul. Lubicz 25 A

31-503 Kraków

E-mail:wilka@inig.pl 